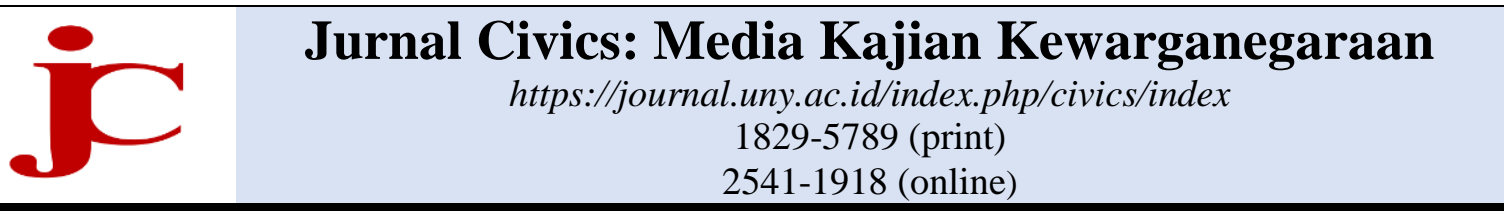

\title{
Pengintegrasian nilai-nilai kearifan lokal dalam pendidikan multikultural
}

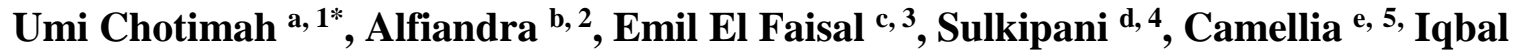 Arpannudin $\mathrm{f}, 6$}

a, b, c, d, e Fakultas Keguruan dan Ilmu Pendidikan, Universitas Sriwijaya, Indralaya, Indonesia

${ }^{\mathrm{f}}$ Fakultas Ilmu Sosial, Universitas Negeri Yogyakarta, Sleman, Indonesia

${ }^{1}$ umi.chotimah@fkip.unsri.ac.id; ${ }^{2}$ alfiandra62@yahoo.com; ${ }^{3}$ emil_faisal@ymail.com;

${ }^{4}$ sulkipani@fkip.unsri.ac.id; ${ }^{5}$ liacamel47@yahoo.com; ${ }^{6}$ arpannudian@uny.ac.id

*korespondensi penulis

\begin{tabular}{|c|c|}
\hline Informasi artikel & ABSTRAK \\
\hline $\begin{array}{l}\text { Sejarah artikel: } \\
\text { Diterima }\end{array}$ & \multirow{4}{*}{$\begin{array}{l}\text { Tujuan artikel ini adalah untuk mengidentifikasi dan } \\
\text { mengintegrasikan nilai-nilai kearifan lokal masyarakat dalam } \\
\text { memperkuat integrasi nasional melalui pendidikan multikultural. } \\
\text { Penelitian ini dilakukan dengan menggunakan pendekatan } \\
\text { kualitatif dengan metode studi kasus. Nilai-nilai kearifan lokal } \\
\text { masyarakat dalam adat pernikahan kelima suku tersebut secara } \\
\text { umum terdiri dari nilai ketuhanan, persatuan, dan kerakyatan } \\
\text { yang tercermin dalam prosesi sebelum pernikahan, saat } \\
\text { pernikahan, dan setelah pernikahan. Dengan demikian, nilai-nilai } \\
\text { kearifan lokal masyarakat tersebut pada dasarnya merupakan } \\
\text { nilai-nilai yang secara umum terdapat di setiap daerah yang dapat } \\
\text { memperkuat integrasi nasional. }\end{array}$} \\
\hline : 24-02-2018 & \\
\hline Dipublikasikan & \\
\hline \multirow[t]{2}{*}{$\begin{array}{l}\text { Kata kunci: } \\
\text { Kearifan lokal } \\
\text { Multikultural } \\
\text { pernikahan }\end{array}$} & \\
\hline & ABSTRACT \\
\hline $\begin{array}{l}\text { Keywords: } \\
\text { Local genius } \\
\text { Multicultural } \\
\text { Wedding ceremony }\end{array}$ & $\begin{array}{l}\text { Integrating local genius values into multicultural education. } \\
\text { This article was aimed at identifying and integrating localwisdom } \\
\text { values fostering national integration through multicultural } \\
\text { education. It was a qualitative research with case study as its, } \\
\text { method. Local wisdom values embeded in the all of five tribes, } \\
\text { marriage are the believe in God, Humanity, unity, and } \\
\text { democracy. In other words, these local wisdom are in common } \\
\text { among society members and can enhance national integration. }\end{array}$ \\
\hline
\end{tabular}

Copyright $@ 2018$ Umi Chotimah, dkk

\section{Pendahuluan}

Semboyan Bhinneka Tunggal Ika yang diharapkan menjadi perekat kuat masyarakat Indonesia dewasa ini sedang mengalami banyak tantangan. Keberagaman yang menjadi kebanggaan seluruh bangsa Indonesia sering dihadapkan pada kondisi yang dibuat oleh kelompok-kelompok tertentu yang justru tidak sejalan dengan hakikat ke-Bhinneka-an yang sudah disepakati oleh para pendiri bangsa. Dinamika sosial saat ini menunjukkan berbagai tindakan yang menggambarkan perubahan sosial ke arah negatif, diantaranya adalah semakin menguatnya paham primordial, kedaerahan di tengah keberagaman, intoleran, ujaran kebencian, serta perilaku-perilaku asosial lainnya yang menjurus pada praktik bernuansa SARA (Suku, Agama, Ras, dan Antar golongan).

Kondisi tersebut sejatinya adalah masalah bersama. Masalah yang terjadi di tengah-tengah kehidupan yang multikultur. Masyarakat multikultur pada prinsipnya mengakui adanya perbedaan antar golongan sebagai bentuk keniscayaan kodrati dari diciptakannya manusia secara bersuku-suku 
dan berbangsa-bangsa agar saling kenal mengenal dan hidup berdampingan. Dengan kata lain, nilai ketuhanan tersebut mengisyaratkan multikulturalisme adalah kepastian dan harus disikapi dengan kebijaksanaan. Sejatinya saling menghormati, tenggang rasa, toleransi serta sikap luhur lainnya adalah nilai-nilai kearifan lokal masyarakat Indonesia telah yang dikenal luas sejak lama. Kearifan lokal adalah semua bentuk pengetahuan, keyakinan, pemahaman, atau wawasan serta adat kebiasaan atau etika yang menuntun perilaku manusia dalam kehidupan (Keraf, 2010). Dengan demikian diketahui bahwa kearifan lokal merupakan hasil dari akal budi manusia dalam bentuk pengetahuan dan keyakinan serta adat kebiasaan yang diyakini kebenarannya dalam kehidupan manusia.

Wilayah nusantara yang terdiri dari ratusan suku bangsa, memiliki kearifan lokal masing-masing yang syarat dengan nilai-nilai kerukunan dalam keberagaman. Akan tetapi ketidak mampuan sekelompok masyarakat dalam menyikapi kehidupan yang multikultur telah mengenyampingkan nilai-nilai kearifan lokal yang ada. Akibatnya adalah terjadinya konflik sosial baik secara vertikal maupun horizontal. Oleh sebab itu, diperlukan upaya strategis untuk membangun kembali nilainilai kearifan lokal masyarakat, diantaranya melalui pendidikan. Hal tersebut dikarenakan Pendidikan dikatakan sebagai instrumen enkulturasi nilai-nilai budaya yang efektif kepada peserta didik (El Faisal \& Sulkipani, 2016). Kemudian Fitriyanti, dkk (2016) mengungkapkan one of the efforts to preserve it is through the utilization of local culture in the educational process. Pendidikan sebagai upaya yang sistematis dan terencana akan memberikan dampak positif secara holistik dan masif dalam menanamkan nilai-nilai kearifan lokal masyarakat.

Pendidikan Multikultural merupakan suatu program penanaman kesadaran hidup dalam kebudayaan yang beragam. Pada prinsipnya, pendidikan multikultural ini dapat dilaksanakan pada berbagai lingkungan, baik keluarga, sekolah, maupun masyarakat, sehingga kesadaran akan keberagaman akan dipahami secara utuh dan menyeluruh. Multikultural dipahami sebagai kehidupan yang berdekatan antara satu atau beberapa budaya (Karasik \& Pomortseva, 2015). Dengan kata lain, multikultural dikatakan sebagai keberagaman budaya. Keberagaman budaya yang sebagai hasil pemikiran dan memberikan manfaat bagi masyarakat. Keberagaman dalam konteks multikultural harus dipahami sebagai diferensiasi sosial secara horizontal. Artinya, semua budaya memiliki nilai luhur masing-masing dalam tata laksananya. Dengan demikian, perbedaan dalam keberagaman tersebut tidak membicarakan eksistensi budaya satu daerah terhadap daerah yang lain. Karena kebudayaan masing-masing daerah pada dasarnya adalah komposisi dari kebudayaan nasional Indonesia yang dijamin pemerintah keberadaannya. Seperti yang tertuang dalam Pasal 32 UUD 1945 bahwa "Negara memajukan kebudayaan nasional Indonesia di tengah peradaban dunia".

Pada dasarnya masing-masing kebudayaan memiliki nilai kearifan lokal yang memiliki kesamaan makna dalam konteks kebudayaan nasional. Sebagai contoh, budaya musyawarah pada masyarakat Palembang yang dikenal dengan istilah "berembug" dan masyarakat Lampung menyebutnya dengan istilah "buhippun”, dan istilah-istilah lain yang maknanya adalah kegiatan menghimpun aspirasi untuk tujuan bersama. Kearifan lokal masyarakat merupakan jati diri atau dalam skala nasional dikenal dengan identitas nasional. Seperti yang dikemukakan oleh Chotimah. (2016) bahwa local wisdom can be used as a builder of the nation's character. Jati diri bangsa sebagai dasar pengembangan kreativitas budaya sangat diperlukan agar bangsa Indonesia tetap eksis dalam menghadapi globalisasi (Kaelan dan Zubaedi, 2007).

Oleh sebab itu, integrasi nilai-nilai kearifan lokal dalam menguatkan integrasi nasional menjadi langkah strategis yang diharapkan mampu mengantisipasi setiap tindakan intoleran dalam kehidupan sosial. Berdasarkan uraian tersebut, maka diperlukan kajian mendalam mengenai integrasi nilai- 
nilai kearifan lokal untuk menguatkan integrasi nasional melalui pendidikan multikultural yang sistematis dalam bentuk penelitian.

\section{Metode}

Penelitian ini dilaksanakan di Kabupaten Ogan Komering Ulu Selatan, Kabupaten Lahat, Kabupaten Ogan Ilir, Kota Palembang, dan Kota Yogyakarta dengan masa penelitian selama 4 bulan. Penentuan lokasi tersebut dengan pertimbangan bahwa Suku Komering, Pasemah, Ogan, Palembang, dan Sunda terdapat di lima kabupaten/kota tersebut dan merupakan suku-suku besar serta representasi dari suku-suku lainnya yang ada di Provinsi Sumatera Selatan dan Jawa barat. Subjek penelitian dalam penelitian ini adalah masyarakat adat Suku Komering, Pasemah, Ogan, Palembang, dan jawa serta pihak-pihak lain yang memiliki kompetensi terhadap kebudayaan adat pernikahan dari masingmasing suku tersebut (purposive sampling). Metode yang digunakan adalah metode penelitian deskriptif. Penelitian deskriptif mampu menjabarkan suatu fenomena dengan prosedur ilmiah untuk menjawab masalah secara aktual (Sugiyono, 2012).

Teknik analisis data yang digunakan dalam penelitian ini merupakan teknik analisis data kualitatif yang terdiri dari tiga tahapan, yaitu: reduksi data (pemilihan dan penyederhanaan data mentah), penyajian data, dan verifikasi data atau kesimpulan. Ketiga tahapan tersebut saling berhubungan karena pengumpulan dan analisis data dalam penelitian kualitatif berlangsung secara terus menerus.

\section{Hasil dan Pembahasan}

Objek penelitian ini adalah adat pernikahan Suku Komering, Ogan, Pasemah, Palembang, dan Sunda yang berada di Kabupaten Ogan Komering Ulu Timur, Lahat, Ogan Ilir, Tasikmalaya, Kota Palembang. Data yang dikumpulkan meliputi data pada sebelum hari pernikahan, pada saat hari pernikahan, dan setelah prosesi pernikahan masing-masing suku.
Pernikahan merupakan tahapan dalam kehidupan manusia yang sangat sakral yang melibatkan berbagai tahapan peristiwa yang mengiringinya. Pada momen ini terjadi sebuah ikatan janji suci sepasang manusia di hadapan Tuhan untuk hidup bersama sebagai wujud keimanan dan kepatuhannya kepada sang pencipta. Momen pernikahan selalu menarik untuk diikuti dan disaksikan. Pernikahan dalam Undang-Undang Nomor 1 Tahun 1974 Tentang Perkawinan disebut dengan perkawinan. Pernikahan berasal dari kata nikah yang berarti perjanjian antara lakilaki dan perempuan untuk bersuami istri (dengan resmi) (Pusat Bahasa, 2008, hal. 1074). Sementara itu perkawinan berasal dari kata kawin yang berarti " 1 . perjodohan lakilaki dengan perempuan menjadi suami-istri; nikah; 2 beristri atau bersuami; nikah; 3 cak bersetubuh" (Pusat Bahasa, 2008, hal. 697). Dalam konteks penelitian ini, peneliti menganggap bahwa pernikahan dan perkawinan adalah padanan kata yang memiliki arti sama.

Masyarakat adat, Suku Komering, Ogan, Pasemah, Palembang, dan Sunda yang berada di Kabupaten Ogan Komering Ulu Timur, Lahat, Ogan Ilir, Tasikmalaya, Kota Palembang memiliki pandangan hidup dan sikap hidup, yang keduanya sama-sama berorientasi pada nilai-nilai kebaikan dan memiliki pandangan hidup yang santun, religius, dan lebih cenderung mementingkan dunia akhirat (Jayanti, 2013). Menurut masyarakat Sunda, laki-laki dan perempuan diciptakan oleh Tuhan agar bersatu menjadi loro-loronong atunggal. Dengan pernikahan, laki-laki dan perempuan dipersatukan oleh sang pencipta menjadi satu roh, satu jiwa. Karena filosofi pernikahan bagi masyarakat sunda adalah demikian, maka perceraian tidak boleh dilakukan atau haram hukumnya apabila dilakukan, kecuali kehendak Tuhan atau salah satunya meninggal (Harsojo, 2003, hal. 45).

Pernikahan dalam masyarakat Sunda berkaitan erat dengan nilai-nilai kesakralan sebagai perwujudan ketaatan orang Sunda terhadap Allah SWT. Hal ini dimanifestasikan dalam beragam adat-adat 
dalam ritual upacara pernikahan adat Sunda yang sarat makna tentang kehidupan. Keterkaitan antara ritual budaya dan agama dijelaskan oleh Durkheim bahwa agama adalah sesuatu yang amat bersifat sosial. Artinya, bahwa dalam setiap kebudayaan, agama adalah bagian yang paling berharga dari seluruh kehidupan sosial. Ia melayani masyarakat dengan menyediakan ide, ritual dan perasaan-perasaan yang akan menuntun seseorang dalam hidup bermasyarakat (Sanaky, 2005, hal. 23).

Ritual diartikan sebagai perilaku formal yang ditentukan untuk acara-acara tidak seperti rutinitas teknis yang mengacu pada keyakinan mistis (atau non-empiris) atas makhluk atau kekuasaan dianggap sebagai penyebab pertama dan terakhir semua efek (Bowie, 2006). Upacara yang dimaksud dalam tulisan ini adalah tingkah laku atau perbuatan yang terikat pada aturan-aturan tertentu menurut adat atau agama (Pusat Bahasa, 2008, hal. 1595). Upacara adat merupakan istilah yang apabila dimasukkan dalam kajian Antropologi maka istilah ini sejalan dengan upacara daur hidup atau rites of passage yang lebih cenderung pada seremoni, di mana di dalamnya ada sejumlah ritual (Maulana, 2013, hal. 626). Trice menyebutnya dengan "A system of several rites connected with a single occasion or event"(Trice \& Beyer, 1985). Disebut upacara dalam penelitian ini karena lebih dekat ke dalam seremonial pelaksanaan pernikahan dalam adat Sunda, yang terdiri dari sejumlah urutan ritual untuk kegiatan pernikahan adat.

Pada tahap awal dari proses pernikahan adalah proses lamaran. Proses lamaran ini pada dasarnya merupakan proses pertemuan kedua belah pihak yang meliputi calon mempelai laki-laki dan calon mempelai perempuan serta keluarganya masing-masing. Tujuan dari diadakannya lamaran ini adalah sebagai penyampaian keinginan dari keluarga calon mempelai laki-laki untuk mempersunting calon mempelai perempuan, dan apabila diterima selanjutnya adalah menyepakati hari pernikahan (akad nikah). Pada masyarakat adat Palembang acara lamaran disebut dengan istilah "mutus kato", adat Pasemah mengenal istilah lamaran dengan sebutan "ngantat palayan", suku Komering menyebutnya dengan istilah "pengatu", dan dalam adat suku Sunda disebut "nendeung omongan". Penggunaan ragam bahasa yang digunakan biasanya berupa bahasa-bahasa simbolik yang penuh makna. Seperti yang dikatakan oleh Djawanai (2011) bahwa bahasa dalam acara ritual atau upacara adat memiliki ragam bahasa yang tinggi yang berbeda dengan ragam yang digunakan dalam percakapan individu belaka karena bahasa dalam upacara adat mengandung pesan-pesan leluhur yang merupakan wacana sosial yang tentunya dapat diterapkan dalam kehidupan. Selain itu, bahasa dalam upacara adat menguraikan secara rinci tentang hubungan sosial antar manusia, hubungan antara alam dengan manusia, hubungan spiritual manusia dengan segala ciptaan yang merupakan kesadaran kolektif dari kelompok masyarakat yang menjalankannya (Kurniasih, 2012, hal. 412). Djawanai (2011)) menguraikan bahwa dalam upacara adat diperlukan kata-kata bijak yang sudah ada sejak zaman leluhur yang biasanya berbentuk metafora. Ungkapan metafora sangat kuat digunakan karena nilainilai tentang kehidupan disampaikan secara tidak langsung dan mengandung amanat bagaimana bertingkah laku dalam kehidupan individu dan kehidupan sosial di masyarakat.

Nilai-nilai yang terkandung dalam proses lamaran meliputi nilai ketuhanan, nilai kemanusiaan, dan nilai permusyawaratan. Nilai ketuhanan tersebut diaktualisasikan dalam bentuk puji-pujian kepada Tuhan Yang Maha Esa, melalui doa dan salam keagamaan yang dilakukan. Nilai kemanusiaan dalam konteks ini dapat dilihat dalam bentuk penghargaan dan penghormatan keluarga calon mempelai laki-laki pada saat mendatangi rumah keluarga calon mempelai perempuan. Selanjutnya adalah nilai permusyawaratan yang dapat dilihat pada saat dilakukannya musyawarah dalam menentukan waktu akad nikah (pernikahan).

Proses selanjutnya adalah proses pada hari pernikahan yang pada masing-masing 
suku disebut dengan istilah yang sama, yaitu akad nikah. Inti dari proses akad nikah adalah "ijab qobul" merupakan proses pernyataan secara terbuka dari wali nikah mempelai perempuan untuk menikahkan anaknya tersebut kepada mempelai laki-laki, yang disaksikan oleh para saksi yang telah ditetapkan sebelumnya, serta disahkan oleh pemerintah dalam hal ini adalah kementerian agama. Dengan disahkannya akad nikah tersebut maka mempelai laki-laki dan perempuan dinyatakan sah sebagai suami istri baik secara hukum agama maupun hukum negara.

Pada proses ini, nilai-nilai yang terkandung adalah nilai ketuhanan, nilai kemanusiaan, dan nilai persatuan. Seperti halnya pada proses lamaran, pada saat akad nikah juga dilakukan puji-pujian kepada Tuhan Yang Maha Esa sebagai wujud syukur atas pernikahan yang dilakukan. Nilai kemanusiaan yang dapat dilihat pada saat kedua mempelai menyalami dan mencium tangan kedua orang tua, serta para tamu yang hadir. Adapun nilai persatuan yang tergambarkan dalam proses tersebut adalah berbaurnya keluarga dari kedua mempelai tanpa memandang latar belakang sosial.

Setelah akad nikah, proses selanjutnya yang merupakan tahap akhir dari prosesi pernikahan. Masing-masing masyarakat adat tersebut memiliki kekhasan dalam penyelenggaraan acara tersebut. Pada masyarakat Pasemah dikenal dengan istilah "lingko'an" yang merupakan acara hiburan oleh para remaja. Masyarakat Komering mengadakan acara yang disebut "sadai badai", yang dilakukan dengan cara keluarga dari pihak laki-laki dan pihak perempuan berkumpul di rumah keluarga pihak perempuan untuk memusyawarahkan nama panggilan antar keluarga mempelai. Adapun masyarakat suku Sunda mengelar acara yang dikenal dengan istilah "numbas" yang berarti membagikan makanan kepada tetangga, keluarga besar, keluarga mempelai laki-laki, serta keluarga jauh yang datang menghadiri acara pernikahan. Pada dasarnya semua bentuk kegiatan yang dilakukan pada akhir kegiatan pernikahan adalah sebagai bentuk syukur atas telah diselenggarakannya pernikahan, serta ucapan terima kasih kepada semua pihak yang sudah memberikan bantuan baik secara langsung maupun tidak dalam penyelenggaraan pernikahan tersebut.

Nilai-nilai kearifan lokal yang tergambarkan pada tahap akhir ini adalah nilai ketuhanan, permusyawaratan, dan nilai persatuan. Nilai ketuhanan akan mewarnai dari setiap proses pernikahan. pada tahap akhir ini doa dipanjatkan sebagai wujud syukur atas telah dilangsungkannya pernikahan. nilai kemanusiaan dapat dilihat pada proses kumpul keluarga setelah pernikahan dilangsungkan, dan nilai persatuan yang terlihat pada saat gotong royong yang dilakukan oleh keluarga mempelai dan para masyarakat sekitar yang turut membantu membersihkan tempat dilangsungkannya pernikahan.

Berdasarkan hasil penelitian tersebut diketahui bahwa dalam prosesi adat pernikahan Suku Komering, Pasemah, Ogan, Palembang, dan Sunda mengandung nilainilai kearifan lokal yang mencerminkan keluhuran bangsa sebagai hasil dari peradaban kebudayaan yang bernilai tinggi. Nilai-nilai tersebut tentunya bersumber dari ideologi bangsa (Pancasila) yang mampu memperkuat integrasi nasional melalui tata laksana setiap tahapan dari prosesi sebelum hari pernikahan, saat hari pernikahan, dan setelah hari pernikahan berlangsung. Kearifan lokal dalam bentuk adat pernikahan tersebut memiliki nilai-nilai yang tetap terjaga sampai sekarang. walaupun terjadi pergeseran bentuk atau tata laksana, namun tidak mengubah esensi nilai yang terkandung di dalamnya. Hal tersebut sejalan dengan pendapat bahwa kearifan lokal sebagai kebijaksanaan yang bersumber pada nilai-nilai yang dianggap baik dan benar serta bertahan dalam waktu yang lama (Mariane, 2014).

Nilai-nilai kearifan lokal tersebut bersumber dari nilai-nilai dasar Pancasila, yang merupakan dasar negara dan pandangan hidup bangsa Indonesia. Dengan demikian, nilai-nilai kearifan lokal masyarakat pada hakikatnya dapat dijadikan sebagai instrumen penguatan integrasi nasional. Kondisi 
tersebut dikarenakan kearifan lokal itu sendiri yang dapat dipahami sebagai pengetahuan antar generasi yang berguna bagi masyarakat saat berhubungan dengan keluarga, tetangga, masyarakat lain, dan lingkungan sekitar (Kongprasertamorn, 2007).

Sejatinya kearifan lokal merupakan bagian dari identitas masyarakat Indonesia yang bersifat dinamis, sehinga perubahan zaman akan membawa pengaruh bagi kearifan lokal yang ada di masyarakat. Dengan demikian, diperlukan partisipasi dan peran serta dari semua komponen masyarakat untuk menjaga nilai-nilai kearifan lokal. Kearifan lokal masyarakat menjadi faktor pendorong eksistensi suatu bangsa dan negara, karena menurut Toyenbee (Kaelan \& Zubaidi, 2007) agar bangsa dan negara Indonesia tetap eksis di tengah arus deras globalisasi maka masyarakat Indonesia harus tetap menempatkan jati diri dan identitas nasional sebagai dasar bertindak dalam era modern.

Nilai-nilai kearifan lokal yang bersumber dari nilai dasar Pancasila tersebut dipahami sebagai nilai-nilai umum yang berlaku secara nasional. Artinya, walaupun istilah yang digunakan terdapat perbedaan akan tetapi makna filosofis yang terkandung di dalamnya memiliki kesamaan. Dalam konteks integrasi nasional, penghargaan dan penghormatan terhadap nilai-nilai kearifan lokal yang beragam antardaerah menjadi wajib untuk dilakukan. Karena tanpa apresiasi terhadap multikultural maka integrasi nasional tidak akan tercapai dengan baik sesuai harapan. Oleh sebab itu, pendidikan multikultural yang sejatinya sebagai program penanaman kesadaran hidup dalam kebudayaan yang beragam merupakan instrumen yang efektif untuk menanamkan kesadaran terhadap keragaman budaya dalam bentuk kearifan lokal yang tumbuh dan berkembang dalam masyarakat. Dalam praktiknya, pendidikan sebagai suatu sistem menegaskan bahwa Tri Pusat pendidikan meliputi keluarga, sekolah, dan masyarakat. Ketiga lingkungan pendidikan tersebut memiliki tanggung jawab dan perannya masing-masing dalam menanamkan kesadaran terhadap keragaman budaya dalam kehidupan yang multikultural (Al Arifin, 2012).

\section{Simpulan}

Nilai-nilai kearifan lokal masyarakat dalam adat pernikahan suku Komering, Ogan, Pasemah, Palembang, dan Sunda secara umum meliputi nilai-nilai ketuhanan, persatuan, dan kerakyatan, yang tercermin dalam prosesi sebelum pernikahan, dan saat pernikahan, dan setelah hari pernikahan. Nilai-nilai tersebut pada prinsipnya merupakan nilai-nilai dasar yang terdapat di setiap daerah dan dapat memperkuat integrasi nasional. Perwujudan integrasi nasional tersebut dilakukan melalui penanaman kesadaran keberagaman terhadap kearifan lokal masing-masing daerah melalui pendidikan multikultural.

\section{Ucapan terima kasih}

Ucapan terima kasih kepada Rektor Universitas Sriwijaya dan dekan FKIP Universitas Sriwijaya yang telah mefasilitasi penelitian ini, masyarakat adat Suku Ogan, Komering, Palembang, Pasemah, dan Sunda, serta pihak-pihak lain yang sudah memberikan batuan dalam melaksanakan penelitian ini.

\section{Referensi}

Al Arifin, A. H. (2012). The implementation of multicultural education in the educational practices in Indonesia. Jurnal Pembangunan Pendidikan: Fondasi dan Aplikasi, 1(1), 72-82.

Bowie, F. (2006). Anthropology of religion. In R. A. Segal (Ed.), The Blackwell companion to the study of religion (hal. 3-24). Malden, Oxford, Victoria: Blackwell Publishing. https://doi.org/10.1017/CBO9781107 415324.004

Chotimah, U. (2016). Implementation of character education local wisdom charged in basic education level in South Sumatera. In Sriwijaya University Learning and Education International Conference (Vol. 2, hal. 
1221-1238). Indralaya: Sriwijaya University.

Djawanai, S. (2011). Recover and revitalize language diversity. In T. Mckinnon, Nurhayati, A. Subiyanto, M. Suryadi, \& S. Waluyo (Ed.), International Seminar "Language and Shift (hal. 12-21). Semarang: Master Program in Linguistic, Diponegoro University.

El Faisal, E., \& Sulkipani, S. (2016). Pengembangan bahan ajar berbasis muatan lokal pada mata kuliah Pendidikan Kewarganegaraan. Jurnal Civics: Media Kajian Kewarganegaraan, 13(2), 113-126.

Fitriyanti, F., Faisal, E. L., Safitri, S., \& Eriawaty, E. (2016). Development of instructional materials based local wisdom in social studies. In Sriwijaya University Learning and Education International Conference (Vol. 2, hal. 395-408).

Harsojo. (2003). Antropologi dan budaya. Jakarta: Aurora Baru.

Jayanti, V. D. (2013). Makna simbol dalam upacara pernikahan adat Sunda perspektif teori bentuk simbolik Ernst Cassirer. Universitas Gajah Mada.

Kaelan \& Zubaidi, A. (2007). Pendidikan kewarganegaraan untuk perguruan tinggi. Yogyakarta: Paradigma.

Karasik, O., \& Pomortseva, N. (2015). Multicultural challenges: teaching contemporary American literature for Russian philological students. Procedia-Social and Behavioral Sciences, 199(2015), 684-688.

Keraf, A. S. (2010). Etika lingkungan hidup. Jakarta: Penerbit Buku Kompas.

Kongprasertamorn, K. (2007). Local wisdom environmental protection and community development: the clam farmers in Tambon Bangkhunsai, Phetchaburi Province, Thailand. Manusya: Journal of Humanities, 10(1), 1-10.
Kurniasih, E. (2012). Ragam bahasa dalam upacara pra-nikah adat Sunda "Ngeuyeuk Seureuh." In A. Subyanto, Mualimin, \& Prihantoro (Ed.), International Seminar " Language Maintenance Shift II (hal. 411-415). Semarang: Master Program in Linguistic, Diponegoro University in Collaboration with Balai Bahsa Jawa Tengah.

Mariane, I. (2014). Kearifan lokal pengelolaan hutan adat. Jakarta: Rajawali Pers.

Maulana, M. (2013). Upacara daur hidup dalam pernikahan adat Sunda. Refleksi, 13(5), 623-640.

Pusat Bahasa. (2008). Kamus besar Bahasa Indonesia (IV). Jakarta: Pusat Bahasa Kementerian Pendidikan Nasional.

Sanaky, H. (2005). Sakral (sacred) dan profan: studi pemikiran Emile Durkheim tentang sosiologi agama. Yogyakarta.

Sugiyono. (2012). Metode penelitian kuantitatif kualitatif dan $R \& D$. Bandung: Alfabeta.

Trice, H. M., \& Beyer, J. M. (1985). Rites and ceremonials in organizational culture. Research in the Sociology of Organizations, 4(22), 1-70. 